\title{
Oral health related quality of life in Indonesian middle-aged and elderly women
}

\author{
Lindawati S. Kusdhany, ${ }^{1}$ Yuliana Sundjaja, ${ }^{2}$ Sitti Fardaniah, ${ }^{1}$ Raden I. Ismail ${ }^{3}$ \\ ${ }^{1}$ Prosthodontic Department Faculty of Dentistry Universitas Indonesia, Jakarta, Indonesia \\ ${ }^{2}$ Postgraduate Program Faculty of Dentistry Universitas Indonesia, Jakarta, Indonesia \\ ${ }^{3}$ Psychiatric Department Faculty of medicine Universitas Indonesia, Jakarta, Indonesia
}

\begin{abstract}
Abstrak
Latar belakang: Menganalisis kualitas hidup yang berhubungan dengan kesehatan gigi dan mulut pada perempuan usia paruh baya dan lansia. Perempuan paruh baya berusia antara 45-59 tahun dimasukkan sebagai subjek penelitian karena masa ini sangat penting untuk persiapan menyongsong masa lansia. Tindakan pencegahan perlu dilakukan secara dini untuk mencapai kualitas hidup lansia yang optimal. Hasil penelitian ini dapat memberikan informasi dan landasan bagi pengembangan kebijakan bidang kesehatan gigi dan mulut.

Metode: Penelitian ini adalah penelitian potong lintang yang dilakukan di Kecamatan Bekasi Timur, Jawa Barat dengan subyek perempuan usia 45-82 tahun. Pengukuran kualitas hidup yang berhubungan dengan kesehatan gigi dan mulut dilakukan menggunakan kuesioner yang telah diterjemahkan ke Bahasa Indonesia dan telah divalidasi.

Hasil: $86.4 \%$ subjek memiliki kualitas hidup yang berhubungan dengan kesehatan gigi dan mulut dengan kategori baik. Jumlah gigi hilang berkorelasi lemah dengan kualitas hidup yang berhubungan dengan kesehatan gigi dan mulut (koefisien korelasi $=-0,133, P=0,041$ ).

Kesimpulan: Kualitas hidup yang berhubungan dengan kesehatan gigi dan mulut tidak tergantung pada jumlah gigi hilang. Temuan ini membuka wawasan terhadap pentingnya edukasi dan penyuluhan pada perempuan paruh baya dan perempuan lansia mengenai pentingnya menjaga kesehatan gigi dan mulut. Pengembangan kebijakan bidang kesehatan gigi dan mulut agar lebih difokuskan pada tindakan promotif, dan dilaksanakan di pusat pelayanan kesehatan, klinik, rumah sakit dan panti werdha. (Med J Indones 2011; 20:62-5)
\end{abstract}

\begin{abstract}
Background: To assess oral health-related quality of life in Indonesian middle-aged and elderly women. Middleaged women between 45-59 years old were included in this study, because this stage of life is important to prepare them entering the old age. Prevention could be done earlier in order to achieve optimum quality of life for the elderly. The purpose of writing this paper is to inform the policy maker to develop a framework in oral health prevention.

Method: Cross-sectional study was done at East Bekasi district, West Java on 236 women 45-82 years of age. Measurement of health related quality of life was performed using the Oral Health-Related Quality of Life (OHRQoL) questionnaire. This questionnaire has already been translated to Indonesian language and has already been validated.

Result: About $86.4 \%$ of subjects had a good oral health-related quality of life. Number of missing teeth and oral health-related quality of life have a weak correlation (correlation coefficient $=-0.133, P=0.041$ ) .

Conclusion: Oral health-related quality of life did not depend on the number of missing teeth. These findings may have implication for promoting education to middle-aged and elderly women in Indonesia about the importance of oral health.This policy frame work will be recommended to be implemented in hospitals, clinics, community care and institutional care. (Med J Indones 2011; 20:62-5)
\end{abstract}

Key words: chewimg difficulties, number of missing teeth, tooth ache

Active ageing is the process of optimizing opportunities for health, participation and security in order to enhance quality of life as people age. ${ }^{1}$ Elderly must be acknowledged as integral members of society and must have the right to enjoy a good quality of life and full equity in access to the services necessary for optimal health. The positive contribution of older persons Correspondence email to: ira_ismail@yahoo.com to development and as a resource for their families, communities and society must be recognized.

Elderly are valuable national assets, therefore their potency should be maintained to reach optimum quality of life. ${ }^{2}$ The term "quality of life" used widely in various context associated with impact of disease and health on 
personal experiences. ${ }^{3}$ Sometimes they are associated with subjective well-being, happiness, satisfaction, goodness and the like., ${ }^{45}$ Quality of life is a dynamic and subjective blend of biological and psychosocial experiences influenced by personal and sociocultural environments. ${ }^{6}$ Similarly, dental professionals have used the term "oral health-related quality of life" to describe the impact of oral health on a patient's personal experiences.

The optimum quality of life of the elderly can be achieved not only by taking notice of general health condition but also by taking consideration of oral health. According to the policy of the WHO Programme, oral health is integral and essential to general health, it is a determinant factor for quality of life. Oral health and general health are interrelated and proper oral health care reduces premature mortality. ${ }^{7}$

This study was performed to assess oral health-related quality of life in Indonesian middle-aged and elderly women. Several measurements of oral health related quality of life have been developed by researchers. ${ }^{8}$ Based on oral health impact profile (OHIP) developed by Slade (1994), ${ }^{9}$ Ariani et al. (2006) translated OHIP to be fitted in Indonesian elderly population. She also has validated the translated instruments. ${ }^{10}$ In this study we use OHIP that has been translated and validated by Ariani et al. (2006). ${ }^{10}$ Oral health-related quality of life includes the impact of oral health on a patient's personal experiences.

Whilst there are numerous studies about dental disease prevalence in older people, little is known about the impact of oral health on the quality of life. Findings from numerous epidemiological studies revealed that older people frequently had poor oral hygiene, high levels of plaque and calculus and high prevalence of periodontal disease. ${ }^{11}$ Elderly have higher dental caries both in terms of decayed, missing and filled teeth (DMF), and root surface caries. Elderly people are also less likely than any other age group to use dental services. ${ }^{11}$ Feminization of aging in Indonesia can be seen by the proportion of elderly women that are higher than elderly men. Elderly women also have higher life expectancy than elderly men. Middle-aged women between 45-59 years old were included in this study, because this stage of life is important to prepare them entering the old age. Prevention could be done from middle-age stage in order to achieve optimum quality of life for the elderly. In this case the role of dental professionals is very important. The purpose of writing this paper was to give information to the policymaker and help them to develop a framework of oral health prevention.

\section{METHODS}

This study was a cross-sectional study that was done at East Bekasi district, West Java on women aged 4582 years. The subjects were taken consecutively from inhabitants of East Bekasi district West Java Province, Indonesia.

This study was approved by the Ethical Commission of the Faculty of Dentistry, University of Indonesia. The data about a person's subjective well-being with respect to her oral health and functional status was collected and measurements of health related quality of life was performed using Oral Health-Related Quality of Life (OHRQoL) questionnaire. This questionnaire was developed by Ariani (2006) and has already been translated to Indonesian language and has already been validated (Alpha Cronbach coefficient 0.908). ${ }^{10}$

The OHRQoL questionnaire consists of 10 questions to measure a person's subjective well-being with respect to her oral health and functional status. The questionnaire used 0 -4scale, and every question consists of five possible answers, always (0), often (1), sometimes (2), seldom (3) and never (4). The total score for the subjects ranges from 0 - 40. Assessment of oral health related quality of life in this study used the same cut off point from the previous study, which was $25 .{ }^{10}$

Four interviewers had already got trained to use this questionnaire before starting this study. All subjects were interviewed and subjected to dental examination. Dental examination for counting missing teeth was done by 4 postgraduate students majoring in prosthodontics.

All data analysis was performed and tabulated using statistical software and Spearman correlation test was performed to evaluate the relationship between number of missing teeth, age, level of education and oral healthrelated quality of life.

\section{RESULTS}

A total of 236 women agreed to participate and filled in the informed consent form. The profile of subjects is presented in table 1.

Most of the subjects (86.4\%) had a good oral healthrelated quality of life. The Mean value of missing teeth were 8.74 teeth; $67.8 \%$ of subjects had 1-12 missing teeth and $22.88 \%$ subjects had $13-32$ missing teeth. The frequency of each item in Oral Health-Related Quality of Life (OHRQoL) questionnaire is presented in table 2. 
Table 1. Profile of subjects

\begin{tabular}{lll}
\hline Variable & Number & Percentage \\
\hline Age (years) & 103 & \\
$45-54$ & 133 & 43.64 \\
$\geq 55$ & & 56.36 \\
Education & 20 & \\
No education & 40 & 8.48 \\
Elementary school (SD) & 49 & 16.95 \\
Junior highschool (SMP) & 111 & 20.76 \\
High school (SMA) & 11 & 47.03 \\
Academy & 5 & 4.66 \\
University & & 2.12 \\
Number of missing teeth & 22 & \\
0 & 160 & 9.32 \\
1-12 & 54 & 67.8 \\
13-32 & & 22.88 \\
Quality of life & & \\
(oral health related) & 32 & 13.6 \\
Bad & 204 & 86.4 \\
Good & & \\
\hline
\end{tabular}

Table 2. Frequency of each item in (OHRQoL) questionnaire

\begin{tabular}{lccccc}
\hline Item & More often & often & Sometime & seldom & Never \\
\hline $\begin{array}{l}\text { Chewing } \\
\text { difficulties }\end{array}$ & 3 & 33 & 29 & 31 & 140 \\
$\begin{array}{l}\text { Pain during } \\
\text { mastication }\end{array}$ & 1 & 25 & 26 & 31 & 153 \\
$\begin{array}{l}\text { Sensitive teeth } \\
\text { Tooth ache }\end{array}$ & 1 & 35 & 67 & 44 & 89 \\
$\begin{array}{l}\text { Worried about } \\
\text { tooth problem }\end{array}$ & 0 & 60 & 38 & 68 & 70 \\
$\begin{array}{l}\text { Uncomfortable } \\
\text { about appearance }\end{array}$ & 2 & 46 & 33 & 32 & 122 \\
$\begin{array}{l}\text { due to tooth } \\
\text { problem }\end{array}$ & & 27 & 32 & 17 & 158 \\
$\begin{array}{l}\text { Tense due tooth } \\
\text { problem }\end{array}$ & 0 & 13 & 15 & 19 & 189 \\
$\begin{array}{l}\text { Interrupt meals } \\
\begin{array}{l}\text { Avoid certain food } \\
\text { Concentration }\end{array}\end{array}$ & 0 & 20 & 20 & 19 & 177 \\
$\begin{array}{l}\text { affected due to } \\
\text { tooth problem }\end{array}$ & 0 & 75 & 31 & 16 & 104 \\
\hline
\end{tabular}

The result of correlation analysis between Oral HealthRelated Quality of Life (OHRQoL) and several important variables is presented in table 3.

Table 3. Correlation analysis between OHRQoL and several variables

\begin{tabular}{lccc}
\hline & Variable & $\begin{array}{c}\text { Correlation } \\
\text { coefficient* }\end{array}$ & $P$ value \\
\hline Number of missing teeth & - OHRQoL & -0.133 & 0.041 \\
Age & - OHRQoL & 0.066 & 0.312 \\
Level of education & - OHRQoL & 0.071 & 0.278 \\
\hline
\end{tabular}

* Spearman correlation analysis
According to the result shown in table 3 , the number of missing teeth and oral health-related quality of life have a significant but weak correlation

\section{DISCUSSION}

This study showed that for Indonesian middle-aged and elderly women, quality of life was weakly related to tooth loss. On the contrary, several researchers found correlation between oral health and quality of life. They showed that tooth loss was related to difficulties in eating, pain, distress and social isolation. ${ }^{12}$

Hallister et. al. showed that tooth loss in the maxilla was strongly associated with reduced quality of life compared to tooth loss in the mandible. Preserving teeth in the maxilla allows people to communicate, which means that they can take part in social life. Tooth loss in the mandible has no effect on speaking and has no negative esthetic effects. ${ }^{13}$

The different results from our study compared to those of the researhers in other countries may be due to the differences in the way of thinking, education, and social economic factors. Only $6.78 \%$ of our subjects had academic/university degree (Table 1). Moreover, Indonesian people also have a calm and patience personality. They think that general health is more important than oral health, so they are not taking seriously any oral and dental problems. Other researher stated that race and education were associated with oral health related quality of life. ${ }^{14}$

Another study in Indonesia found that prostheses seemed to improve the quality of life among the elderly. ${ }^{15}$ Based on these evidences, we suggest a policy to recommend the involvement of dental professionals in promoting oral health through dental education. This policy should be recommended to be implemented in hospitals, clinics, community care and institutional care.

In conclusion, the result of this study showed that oral health-related quality of life did not have a strong correlation with the number of missing teeth. The subjects took more seriously problems in general health and systemic disease than problems in oral health. These findings may have implication in promoting dental education to the middle-aged and elderly women in Indonesia about the importance of oral health in increasing their quality of life. 


\section{REFERENCES}

1. WHO. A framework for action on women, ageing and health. Geneva: WHO; 2008.

2. WHO. Ageing and health technical report. A glossary of terms for community health care and services for older persons. WHO. 2004;5:3-5.

3. MacEntee M. Quality of life as an indicator of oral health in older people. JADA. 2007;138:475-15.

4. Hayry M. Measuring the quality of life : why, how and what? Theor Med.1991;12(2):97-116.

5. Hunt S. The problem of quality of life. Qual Life Res. 1997;6(2):205-12.

6. MacEntee M. The impact of edentulism on function and quality of life. In: MacEntee M. Implant overdentures: the standard of care for edentulous patients. Chicago: Quintessence; 2003. p. 1-7.

7. Petersen PE, Yamamoto T. Improving the oral health of older people: the approach of the WHO global oral health programme. Community Dent Oral Epidemiol. 2005;31(1):3-24.

8. Locker D, Matear D, Stephens M, Lawrence H, Payne B. Comparison of the GOHAI and OHIP 14 as measures of the oral health related quality of life of the elderly. Community Dent Oral Epidemiol. 2007;35:401-11.

9. Slade GD. Derivation and validation of a short form oral health impact profile. Community Dent Oral Epidemiol. 1997;25:184-90.

10. Ariani N. The relationship of oral health and elderly quality of life. (Thesis). Jakarta:Universitas Indonesia;2006.

11. McGrath C, Bedi R. A study of the impact of oral health on the quality of life of older people in the UK findings from a national survey. Gerodontology.1998;15(2):93-8.

12. Jones J A, Orner M B, Spiro A. Tooth loss and dentures: patients perspectives. Int Dent J. 2003;53:327-34.

13. MC Hallister, Weintraub JA. The association of oral status with systemic health, quality of life and economic productivity. J Dent Educ.1993;57:901-12.

14. Makhija SK, Gilbert GH, Boykin MJ, Litaker MS, Allman RM, Baker PS, et al. The relationship between sociodemographic factors and oral health related quality of life in dentate and edentulous community dwelling older adults. J Am Geriatr Soc. 2006; 54: 1701-2.

15. Septrini M. The relationship of cognitive function and demand to wearing denture in elderly (a study in Borobudur village), [thesis]. Jakarta:Universitas Indonesia; 2010. 